\title{
173 心筋梗塞後左室蒥に対する外科療法の効果と限界
}

\begin{tabular}{|c|c|c|c|c|c|c|c|c|c|c|c|c|c|}
\hline & \multirow[b]{2}{*}{ 元 } & \multirow[b]{2}{*}{ 美 } & \multirow[b]{2}{*}{ 長谷川 } & \multicolumn{4}{|c|}{ 日本大学 第 2 外科 } & \multirow[b]{2}{*}{ 信 } & \multirow[b]{2}{*}{$\equiv$} & \multirow[b]{2}{*}{ 梅 } & \multirow[b]{2}{*}{ 田 } & \multirow[b]{2}{*}{ 正 } & \\
\hline & & & & 隆 & 光 & 北 & 村 & & & & & & 五 \\
\hline 野 & 幸 & 志 & 陸 & 秀 & 智 & 進 & 藤 & 正 & $=$ & 今 & 村 & 好 & 学 \\
\hline & & & 原 & & 泰 & 瀬 & 在 & 幸 & 安 & & & & \\
\hline
\end{tabular}

心筋梗塞症に打ける左室瘤の合併は，ほかの機械的合 併症に比して多く，外科療法によってその予後が良好と なりうる ${ }^{1-3)}$. しかしながら，その切除範囲，冠動脈病 変程度, 術前心機能などの差異により, 生存は得られる あのの, 術後心機能の回復面では必ずしも良好とはいえ ない症例屯観察され，とくに術後急性期では，種々の機 械的補助循環法を要するあのや，長期にわたり心機能回 復が遅延するあのなどさまざまである. 今回, その外科 療法の效果と限界につき検討した。

\section{対象と方法}

左室瘤を伴う陳旧性心筋梗塞症例で, 1 年以上の生存 を得, 術後心臓カテーテル検査および左室造影を行った 24 例を対象亡した，全例男性で，年齢は 39〜 71 歳（平 均 52.0 歳) であり, 外科的治療内容は, 瘤切除のみ 3 例, 瘤切除に中隔穿孔閉銷を併うもの 1 例, さらに瘤切 除に A-C バイパス 1 枝を伴うもの4 例，A-Cバイパス 2 枝を伴うもの 11 例, 同様に 3 枝 3 例， 4 枝 2 例の計 24 例であった. うち 8 例に体外循環離脱目的で IABP を使用し，てのなかに 1 例 LVAD を併用したものがあ った. 残る 16 例では，乙れらを要さなかった．左心機
能を中心に，術前後に扔りる変化上ともに，瘤切除術の 効果ならびに機械的補助循環法の効果と限界についてあ 検討した.

\section{結果と考案}

\section{1. 術前後の左心機能亡 NYHA 分類（図 1)}

心係数㧍よび左室駆出率の術前後における変化は，そ れぞれ術前 $3.4 \mathrm{l} / \mathrm{min} / \mathrm{m}^{2}$ 加ら術後 4.1 , 術前 0.42 から 術後 0.59 一といずれも有意な改善が認められた。 また， NYHA 機能分類も著明に改善し, 左室瘤切除を含む外 科療法の効果が認められだ)。しかしながら, 左室駆出 率について, 術前值 EF 0.4 以上を示す例では術後の改 善率が著明でないのに対し，術前 EF 0.4 以下を示す低 左室機能症例では, 術後の改善率は著明であった。 しか しながら, $\mathrm{EF}$ が $0.2 \sim 0.3$ の高度心機能低下例では, EF 0.4 以下の症例に比してその改善効果はそしいと思 われた，すなわち，重症症例においては，必ずしも外科 療法の効果は著明とはならない可能性が示唆された。

\section{A-C バイパス術の効果}

病変枝数之術前の左心機能の検討では, $0 \sim 2$ 枝病変 群と 3 枝病変群の 2 群間で比較を行うと, 左室駆出率に

Cardiac Index and Ejection Fraction

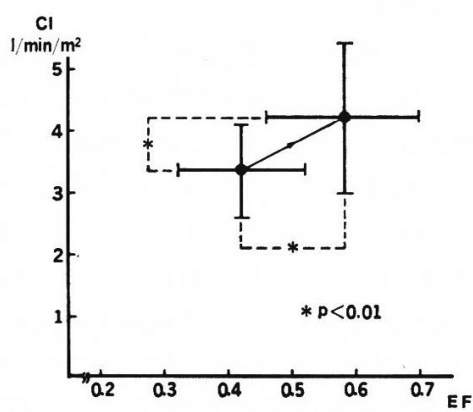

NYHA Classification

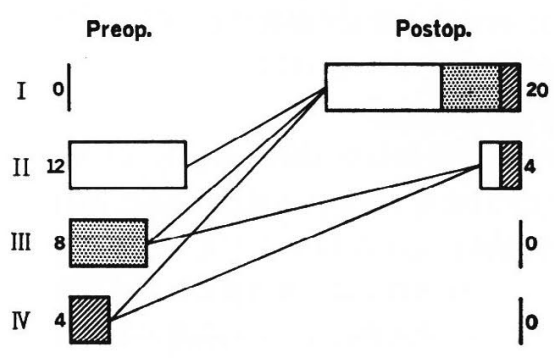

図 1 左室瘤切除術の効果 


\section{左心機能改善率 \\ 術後値 / 術前值}
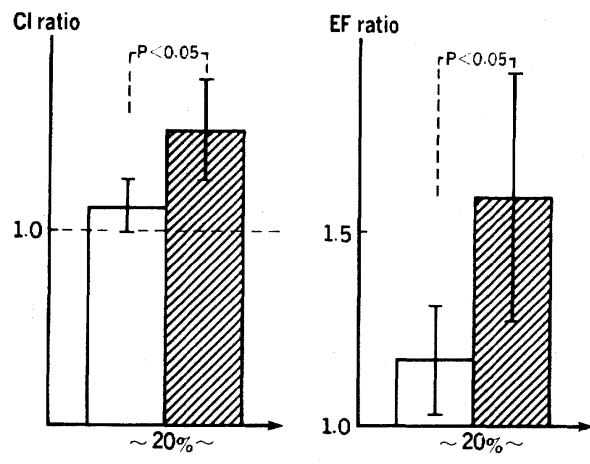

機能心筋収縮率
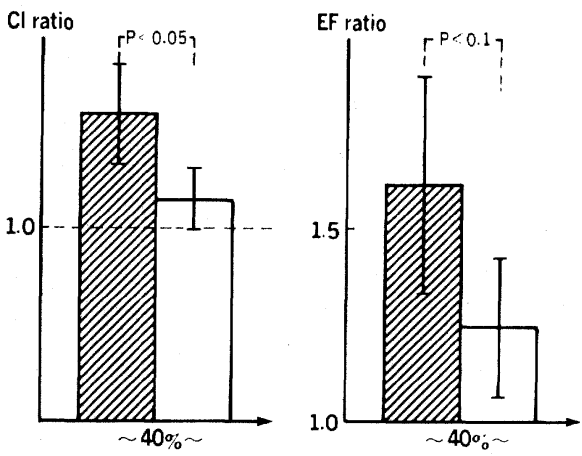

周 径 比

図 2 機能心筋収縮率と左室瘤周径比

関しては 3 枝病変群では有意に低值を示したが，左室拡 張末期圧および心係数に関しでは有意差は認めなかっ た. また，病変血管に対する血行再建の効果について， 完全血行再建群と非完全血行再建群の 2 群にわけて検討 した，完全血行再建群では，CI，LVEDP，EF のいず れの值も術前後に著明な改善が認められるものの, 不完 全血行再建群では，CI，EF の改善は有意であったが， LVEDP は有意でなく，またこれらのパラメータの改善 率は, 完全血行再建群で良好な值を示し, 瘤切除術に A-C バイパス術を併用するととの重要性が確認された.

\section{3. 機能心筋収縮率と周径比}

冠動脈障害程度を比較的良好に反映するとされる心基 部の機能心筋収縮率と左室瘤の周径比 ${ }^{5)}$ につて, おの おの $20 \%$ と $40 \%$ を境にして 2 群にわけ，CI および $\mathrm{EF}$ について術後值を術前值で除した值を各改善率として比 較する之，機能心筋収縮率 $20 \%$ 以下の場合には，CI お よび $\mathrm{EF}$ の術前後の改善率は有意に低值を示した。

同様に，周径比 $40 \%$ 以上を示す症例でも，CI および $\mathrm{EF}$ の改善率は低值にとどまった（図 2 ).

\section{4. 機械的補助循環法の効果}

体外循環離脱目的に使用した IABP ないし LVAD は，救命率の向上には有用であったと思われるが，それ らの使用群, 非使用群における CI らびに EF の術前 後の比較において, 非使用群では, 使用群に比して改善 効果は良好であったが, 使用群における心係数の改善効 果は乏しかった（図３）。すなわち，術前に高度の左心 機能低下があり，体外循環離脱困難に陥るような症例で
CI
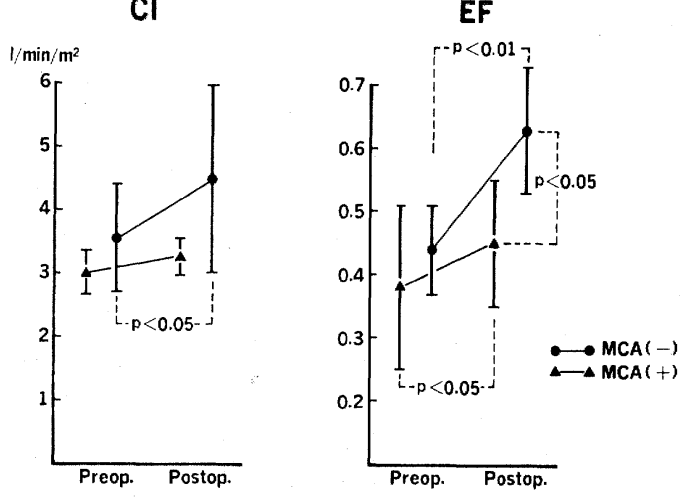

MCA : Mechanical Circulatory Assistance

図 3 機械的補助循環法の効果

は，術後の心機能改善には自ずと制限があると考えら れ，効果の限界を示していると思われた。

\section{5. 症例 6 )}

54 歳の男性で，前壁中隔梗塞に広範囲左室瘤を合併 した症例で，術前の冠動脈造影では，左前下行枝の完全 閉塞と右冠動脈に $50 \%$, 左回旋枝に $75 \%$ の狭窄を認 め, 左室造影では前壁加引心尖部にかけて左室瘤およ び akinesis の部分を認め，機能心筋収縮率 $20 \%$ ，周径 比 $42 \%$, 駆出率 0.29 , 心係数 $3.1 \mathrm{l} / \mathrm{min} / \mathrm{m}^{2}$, LVEDP $27 \mathrm{mmHg}$ を示した，体外循環下に左室瘤広範囲切除, $\mathrm{RCA}$ 乙 $\mathrm{LCX}$ に 2 枝 A-C バイパスを施行したが, 体外循環離脱に LVAD を要したが, 長期生存し, 社会 復帰に至った。術後の検査では，機能心筋収縮率 $28 \%$ ， 
一般演題 冠

aknesis 周径比 $20 \%$ と改善したが, 心係数 $3.4 l / \mathrm{min} /$ $\mathrm{m}^{2}$, EF 0.38 と必ずしも良好な值ではなかった.

\section{結語}

1) 術後の左室駆出率，心係数および NYHA 分類は いずれも有意な改善がみられた。

2) 多枝病変例では術前心機能低下を示すととが多 く,また A-C バイパスの併用により左心機能の改善に は効果的であった。
動 脈 (V)

17: 545

3）機能心筋収縮率 $20 \%$ 以下, 左室瘤周径比 $40 \%$ 以 上では, 術後心機能の改善効果がそしいと思われた.

4 ) 機械的補助循環法により, 救命率は向上するすの の, 術後の左心機能改善効果は亡しかった.

文献 1) 瀬在幸安: 臨 床胸部外科 3: 397, 1983. 2) Loop, F. D. et al. : Ann. Surg. 178: 399, 1973. 3) Olearchyk, A. S. et al.: J. Thorac. Cardiovasc. Surg. 88: 544, 1984. 4) 川野幸志：胸部外科学会誌 $32: 2067,1984$. 5) 小原邦義 : 日胸外会誌 25: 907, 1977. 6) 塩野元美ほか：人工藏器 16 : 11, 1987.

174 左心直達手術の安全性に関する臨床的検討

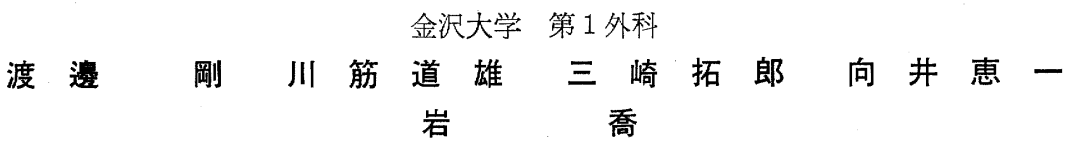

正常左心室に対する直達手術はその心機能に与える影 響を考慮し，あまり行われていない．しかし左心室切開 を余儀なくされる症例もあり, 将来その必要性む増加し てくるあのと思わ机る. 本稿の目的は正常左心室切開の 安全性を，その血行動態ならびに左室造影より得られた 左室容量解析加ら確認するとてろにある.

\section{対象と方法}

対象は当科防いて行われた左心型非虚血性心室性頻 拍症根治術症例 (以下 VT 群), および左心室瘤切断術 (以下 LVA 群) 症例それぞれ 9 例， 9 例計 18 例であ る. 手術方法は, VT 群は, 胸骨正中切開にて心臟に 到達し人工心肺を用いた常温体外循環下に頻拍起源を同 定した後, 大動脈遮断し心尖部より左室前壁扝よび左室 後壁に左心室切開を加え, 凍結凝固を加えた後直接縫合 閉鎖した. LVA 群は左心室瘤を切除, 直接縫合閉鎖し た. 左室容量解析には，右前 30 度斜位 (RAO) 飞お いて得られた左室造影により行った。 心係数 (CIa), 左心駆出率 (EF), area-length 法 ${ }^{1}$ 亿て算出した左室拡 張末期容量係数 (LVEDVI), 左室収縮末期容量係数 (LVESVI)，一回心拍出係数 (SVI), および左室非収 縮部係数 (NCAI) を, また心拍出係数 $(\mathrm{CI})$ を比較検 討した.

LVEDVI $\left(\mathrm{ml} / \mathrm{m}^{2}\right)=$ LVEDV $/$ BSA

$$
\begin{gathered}
\text { LVESVI }\left(\mathrm{ml} / \mathrm{m}^{2}\right)=\text { LVESV } / \mathrm{BSA} \\
\mathrm{SVI}\left(\mathrm{ml} / \mathrm{m}^{2}\right)=\mathrm{LVEDVI}-\mathrm{LVESVI} \\
\mathrm{EF}(\%)=\{(\mathrm{LVEDV}-\mathrm{LVESV}) / \mathrm{LVEDV}\} \times 100 \\
\mathrm{LVISA}\left(\mathrm{cm}^{2}\right)=\pi d^{2} \\
d=\sqrt[3]{6 \mathrm{LVEDV} / \pi} \\
\mathrm{LVV}(\mathrm{ml})=\pi D^{2} L=0.668 A^{2}(\mathrm{CF})^{3} / \mathrm{L}+7.8 \\
\mathrm{NCAI}=\mathrm{NCA} / \mathrm{BSA} \\
\mathrm{NCA} \%(\%)=(\mathrm{NCA} / \mathrm{LVISA}) \times 100
\end{gathered}
$$

左室非収縮部（NCA）の定量化にはその左室造影所見 より観察された形状により central angle method ${ }^{1)}$ お よび graphic integration method を用いた（図1).

(1) Central angle method

$$
\operatorname{NCA}\left(\mathrm{cm}^{2}\right)=2 \pi R^{2}(1-\cos 1 / 2 \theta)(\mathrm{CF})^{2}
$$

(2) Graphic integration method

$$
\begin{aligned}
\mathrm{NCA}\left(\mathrm{cm}^{2}\right) & =\pi(\mathrm{CF})^{2} \sum W_{k}\left(r_{k}+r_{k+1}\right) 2 \pi R h(\mathrm{CF})^{2} \\
& r_{k}=1 / 2 D_{k} \quad \mathrm{CF}=\text { 拡大率 } \\
& \text { 結 } \quad \text { 果 }(\text { 図 } 2,3)
\end{aligned}
$$

\section{1. 左室駆出率 $(\mathbf{E F})$}

左室駆出率は，VT 群では術前平均 $59.3 \pm 9.90 \%$ 術 後平均 $60.1 \pm 10.9 \%$ と変化は認められなかった. LVA 群では術前平均 $38.3 \pm 5.91 \%$ とVT 群に比べ有 意に低下しており，術後は平均 $52.5 \pm 13.2 \%$ と術前に 比べ有意に上昇した. 